\title{
Serum Values of Copper, Zinc and Selenium in Adults Resident in Kuwait
}

\author{
H. Al-Sayera A. Al-Bader ${ }^{b} \quad$ M. Khoursheed ${ }^{a} \quad$ S. Asfar ${ }^{a}$ \\ T. Hussain $^{c}$ A. Behbehania A. Mathew ${ }^{a} \quad$ H. Dashti ${ }^{a}$ \\ Departments of a Surgery and bPathology, Faculty of Medicine, Kuwait University, and \\ 'Bayan Polyclinic, Kuwait
}

\section{Key Words}

Trace elements · Copper · Zinc · Selenium • Kuwaiti population

\begin{abstract}
Objective: The populations of Kuwait and other Arabian Gulf States are very heterogeneous. Expatriates with different dietary habits constitute approximately $60 \%$ of the $\mathrm{Ku}$ waiti population. The aim of this study was to establish a reference range of trace element levels in the serum of the normal population in Kuwait. Method: A total of 379 healthy males ( $n=262$ ) and females $(n=117)$ of various nationalities living in the State of Kuwait were studied. The serum concentrations of zinc $(\mathrm{Zn})$, copper $(\mathrm{Cu})$ and selenium (Se) were measured and the copper/zinc $(\mathrm{Cu} / \mathrm{Zn})$ ratio was calculated. Results: The study estab-
\end{abstract}

\begin{tabular}{ll}
\hline KARGER & ( ) 2000 S. Karger AG, Basel \\
Fax +41613061234 $3471 / 00 / 0092-0139 \$ 17.50 / 0$ \\
$\begin{array}{l}\text { E-Mail karger@karger.ch } \\
\text { www.karger.com }\end{array}$ & $\begin{array}{l}\text { Accessible online at: } \\
\text { www.karger.com/journals/mpp }\end{array}$
\end{tabular}

lished the serum $\mathrm{Zn}, \mathrm{Cu}$ and Se levels in the studied population. The results showed that there was no significant difference in the serum levels of these elements among the different nationalities tested. A significantly higher serum $\mathrm{Cu}$ level and $\mathrm{Cu} / \mathrm{Zn}$ ratio were seen in females. Conclusion: These findings can form the basis and reference for any future studies on trace elements in different pathologic conditions in the Arabian Gulf region.

Copyright ( 92000 S. Karger AG, Basel

\section{Introduction}

The importance of trace elements such as zinc $(\mathrm{Zn})$, copper $(\mathrm{Cu})$ and selenium $(\mathrm{Se})$ in health and disease have not been seriously considered until recently. Zinc plays an im- 
portant role in immunity, wound healing, growth, reproduction, and metabolism of proteins and carbohydrates [1,2]. Zinc deficiency was shown to predispose to various infections and also cause growth retardation [3, 4]. Zinc forms an integral part of more than 300 enzymes including alkaline phosphatase, glutamic acid dehydrogenase, carboxypeptidase and RNA polymerase [5]. The majority of plasma $\mathrm{Zn}$ is bound to albumin [6]. Ceruloplasmin and macroglobulin also appear to exhibit great affinity for plasma $\mathrm{Zn}$ [6].

Copper is a component of ceruloplasmin, ferroxidase II, lysyl oxidase, monoamine oxidase, $\mathrm{Zn}-\mathrm{Cu}$ superoxide dismutase, tyrosinase, dopamine $\beta$-hydroxylase and cytochrome c oxidase [7]. Copper is important for erythropoiesis, leukopoiesis, bone mineralization, elastin and collagen cross-linking, oxidative phosphorylation, catecholamine metabolism, melanin formation and antioxidant protection of cells [7-9]. Copper is mainly bound to ceruloplasmin $(90 \%)$, only $5-10 \%$ is loosely bound to albumin and other amino acids like histidine, threonine and glutamine [10]. In erythrocytes, the major portion of $\mathrm{Cu}$ is present within the enzyme superoxide dismutase, which is also present in the liver and brain [11]. Copper is involved in the synthesis of hemoglobin, formation of collagen, skeletal development, pigment formation, maintenance of the myelin sheath and function of the immune system [12, 13].

Oxidative stress can result from deficiency of trace elements such as $\mathrm{Zn}, \mathrm{Cu}$ and Se. Zinc is involved in stabilizing the cell membrane and prevents oxidative destruction by free radicals [14]. Selenium is an essential trace element for humans; it is a component of the enzyme glutathione peroxidase $[15,16]$. It exerts its protective effect [17] against oxidative damage by decreasing the amount of free radicals and increasing the synthesis of glutathione peroxidase. This enzyme along with other cellular antioxidants such as vitamin $\mathrm{E}$, catalase and superoxide dismutase [18] has the ability to protect biomembranes from oxidative destruction. Thus it is possible that deficiencies of these elements may contribute to the development and progression of certain diseases. It has also been reported that $\mathrm{Se}$ increases the growth of human fibroblasts in culture [19].

Thus establishing the normal range of trace element levels in the sera of healthy individuals in a geographical area is of value to form a reference range for further studies in the region.

\section{Materials and Methods}

Blood samples were collected from 379 disease-free individuals living in the central part of Kuwait. Seventy-five percent of these individuals were people accompanying patients to Bayan Clinic (polyclinic) and the remaining $25 \%$ were from the staff of Kuwait University. Informed consent from volunteers was taken prior to blood collection. In the female volunteers, it was ascertained that they were not pregnant at the time of blood sampling. However, no information was collected from the females with respect to the usage of oral contraceptives or any other hormonal preparation. Approximately $10 \mathrm{ml}$ of venous blood was collected from each individual in special metal-free glass tubes free of anticoagulant, using the standard venipuncture technique (vacutainer trace element tubes with royal blue rubber stopper, Becton-Dickinson Vacutainer System). The blood samples were allowed to clot and then centrifuged for $15 \mathrm{~min}$ at $2,500 \mathrm{rpm}$. The serum was separated into metal-free plastic tubes and stored at $-20^{\circ} \mathrm{C}$ until analysis.

Zinc and $\mathrm{Cu}$ concentrations were estimated in the samples using flame atomic absorption spectrophotometry (AAS). The samples were diluted (1:10) with deionized, double-distilled water. Standards (prepared in deionized, double-distilled water) were run in the range of $0.1-0.5 \mathrm{ppm}$ and $0.05-0.2 \mathrm{ppm}$ for $\mathrm{Cu}$ and $\mathrm{Zn}$, respectively. The calibration graph was plotted using the concentration method.

Selenium was estimated in the samples by the same technique described above using graphite furnace coupled with a background corrector. Samples were di- 
luted 1:5 in double-distilled deionized water. Selenium standards were prepared in 1\% hydrochloric acid $(\mathrm{HCl})$ and were run in the range of 30-90 ppb. A modifier $(20 \mathrm{mg}$ citric acid in $2 \mathrm{ml} \mathrm{Pd}$ of $500 \mathrm{ppm}$ concentration) was used for the analysis of serum Se. The calibration graph was plotted using the standard addition method so as to eliminate the effect of the matrix, if any.

Trace element stock standards (concentration $1,000 \mathrm{ppm}$ ) were obtained from Fluka Chemika, Switzerland. Trace elements were assayed by AAS (Varian model, spectra AA300+ 400, Australia); $\mathrm{Cu}$ and $\mathrm{Zn}$ were assayed by flame AAS, whereas Se was assayed by graphite tube atomizer (GTA-96). The data on trace elements were analyzed by means of one-way ANOVA for multiple comparisons (Stat-View 4.02 statistics package using Macintosh Centries 650 Computer). The data are expressed as the mean \pm SEM. The results were considered significant if $\mathrm{p}<0.05$.

\section{Results}

Serum $\mathrm{Cu}, \mathrm{Zn}$ and Se were assayed for 379 disease-free individuals living in Kuwait. The population sample was comprised of Egyptians (males 15, females 6), Indians (males 57, females 29), Kuwaitis (males 180, females 76) and Lebanese (males 10, females 6). The mean ages (+ SEM) for the Egyptian, Indian, Kuwaiti and Lebanese males were 39.2 ( \pm 2.38$), 34$ ( \pm 1.29$), 40.3$ ( \pm 1.06$)$ and 36.9 ( \pm 2.66 ) years, respectively (fig. 1). The mean ages ( \pm SEM) for the Egyptian, Indian, Kuwaiti and Lebanese females were $36( \pm 5.28)$, 37 ( \pm 1.49$), 38.3( \pm 1.27)$ and $33.3( \pm 3.86)$ years, respectively (fig. 1). The ages of the resident nationalities used in this study were comparable.

The mean ( \pm SEM) levels of $\mathrm{Cu}(\mathrm{mg} / \mathrm{l}), \mathrm{Zn}$ $(\mathrm{mg} / \mathrm{l})$ and $\mathrm{Se}(\mu \mathrm{g} / \mathrm{l})$ in this population $(\mathrm{n}=$ $379)$ were $1.48( \pm 0.02), 1.03( \pm 0.01)$ and 88.3 ( \pm 1.02$)$, respectively. Analysis and comparison of the data among the nationalities in the study groups (table 1) showed that, in general, there were no significant differences in the serum levels of $\mathrm{Cu}, \mathrm{Zn}$ and Se among the

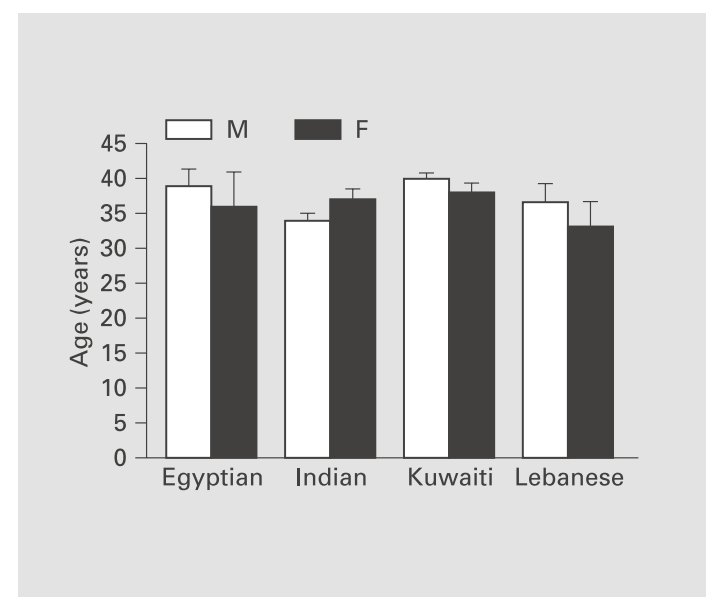

Fig. 1. Age of the population sample. Mean \pm SEM. $\mathrm{F}=$ Female $\mathrm{M}=$ male.

four nationalities tested. However, there were some gender differences. Females in the Indian and Kuwaiti group had significantly lower $\mathrm{Cu}$ when compared to Egyptians $(\mathrm{p}<0.01)$. Furthermore, the $\mathrm{Cu}$ levels of the Kuwaiti females were also significantly lower when compared to those of the Lebanese group. Serum $\mathrm{Zn}$ was comparable among the groups except for the Lebanese females, who had a significantly higher $\mathrm{Zn}$ concentration in comparison to the females of all the other nationalities $(p<0.02)$. Serum Se levels were not significantly different in all the groups. The Indian females, however, showed slightly higher serum Se levels. This increase was significant when compared to the females in the Egyptian group $(\mathrm{p}<0.037)$.

Females in all the nationalities investigated had significantly higher serum $\mathrm{Cu}$ concentrations in comparison to males (fig. 2) and this was reflected by a significantly increased $\mathrm{Cu} / \mathrm{Zn}$ ratio in the females (fig. 4). This tendency was not observed with serum $\mathrm{Zn}$ and Se levels in the four nationalities tested (fig. 3, 5). 


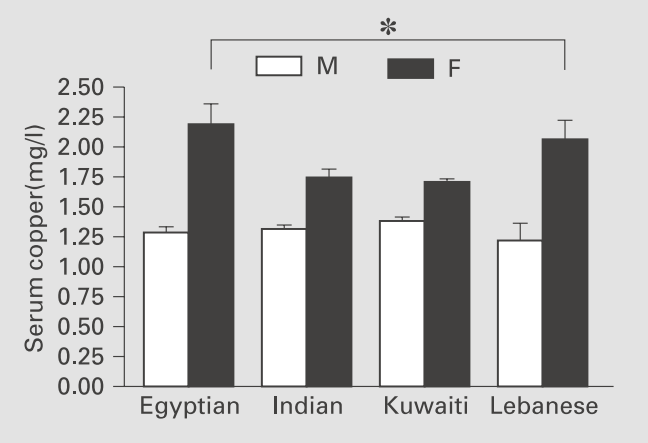

Fig. 2. Serum copper level in different nationalities in males and females. ${ }^{*} \mathrm{p}<0.001$ as compared to males. Mean \pm SEM. $F=$ Female; $M=$ male.

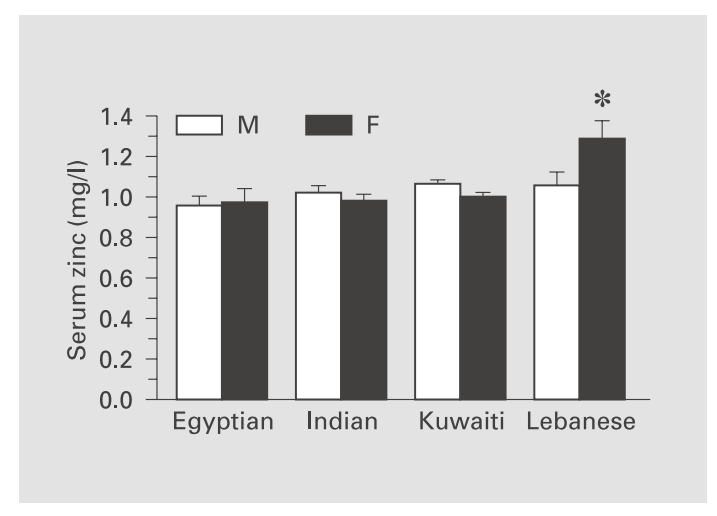

Fig. 3. Serum zinc level in different nationalities in males and females. ${ }^{*} \mathrm{p}<0.02$ as compared to females. Mean \pm SEM. $F=$ Female; $M=$ male.

Table 1. Serum trace elements in a cross section of adults resident in Kuwait

\begin{tabular}{lllll}
\hline Groups & Copper, $\mathrm{mg} / \mathrm{l}$ & Zinc, $\mathrm{mg} / \mathrm{l}$ & $\mathrm{Cu} / \mathrm{Zn}$ & Selenium, $\mu \mathrm{g} / \mathrm{l}$ \\
\hline Egyptians & & & & \\
$\mathrm{M}(\mathrm{n}=15)$ & $1.28 \pm 0.600$ & $0.95 \pm 0.053$ & $1.39 \pm 0.092$ & $83.8 \pm 4.64$ \\
$\mathrm{~F}(\mathrm{n}=6)$ & $2.19 \pm 0.166^{\mathrm{a}}$ & $0.97 \pm 0.072$ & $2.35 \pm 0.269^{\mathrm{a}}$ & $76.3 \pm 7.03$ \\
\hline Indians & & & & \\
$\mathrm{M}(\mathrm{n}=57)$ & $1.32 \pm 0.040$ & $1.02 \pm 0.032$ & $1.33 \pm 0.040$ & $93 \pm 2.51$ \\
$\mathrm{~F}(\mathrm{n}=29)$ & $1.75 \pm 0.074^{\mathrm{a}, \mathrm{d}}$ & $0.97 \pm 0.033$ & $1.85 \pm 0.091^{\mathrm{a}}$ & $94.3 \pm 3.95^{\mathrm{c}}$ \\
\hline Kuwaiti & & & & \\
$\mathrm{M}(\mathrm{n}=180)$ & $1.39 \pm 0.024$ & $1.06 \pm 0.018$ & $1.36 \pm 0.027$ & $87.4 \pm 1.54$ \\
$\mathrm{~F}(\mathrm{n}=76)$ & $1.70 \pm 0.040^{\mathrm{a}, \mathrm{d}, \mathrm{e}}$ & $0.99 \pm 0.027$ & $1.79 \pm 0.059^{\mathrm{a}}$ & $87.6 \pm 2.11$ \\
\hline Lebanese & & & & \\
$\mathrm{M}(\mathrm{n}=10)$ & $1.22 \pm 0.138$ & $1.05 \pm 0.064$ & $1.16 \pm 0.132$ & $80.7 \pm 5.79$ \\
$\mathrm{~F}(\mathrm{n}=6)$ & $2.07 \pm 0.148^{\mathrm{a}}$ & $1.27 \pm 0.094^{\mathrm{b}}$ & $1.64 \pm 0.098^{\mathrm{a}}$ & $85.5 \pm 7.44$ \\
\hline
\end{tabular}

All values are mean \pm SEM. Numbers in parentheses give sample size. $\mathrm{M}=$ Male; $\mathrm{F}=$ female.

a Significantly different from the males within the same group $(\mathrm{p}<0.001)$.

b Signifcantly different from the females in the Egyptian, Indian and Kuwaiti groups $(\mathrm{p}<$ 0.02).

c Significantly different from Egyptian females $(\mathrm{p}<0.037)$.

d Significantly different from Egyptian females $(\mathrm{p}<0.01)$.

e Significantly different from Lebanese females $(p<0.02)$. 


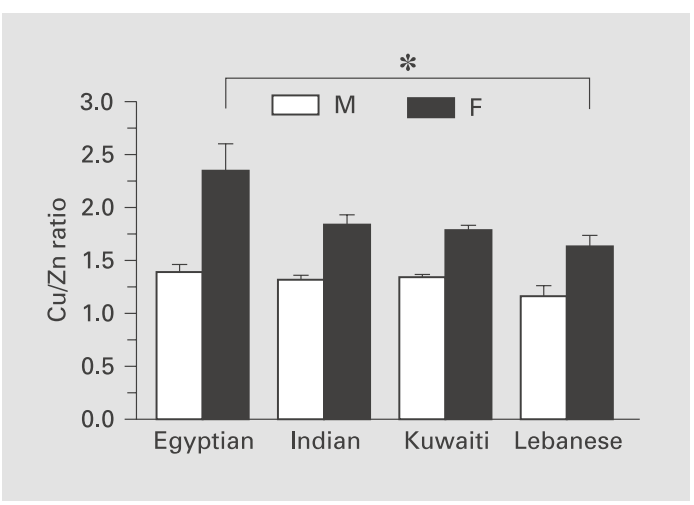

Fig. 4. Copper/zinc ratio in different nationalities in males and females. ${ }^{*} \mathrm{p}<0.001$ as compared to males. Mean \pm SEM. $F=$ Female; $M=$ male .

The reference values for $\mathrm{Cu}$ were different for males and females. The mean $( \pm$ SEM) values for $\mathrm{Cu}(\mathrm{mg} / \mathrm{l})$ in the males $(\mathrm{n}=262)$ and females $(\mathrm{n}=117)$ were $1.37( \pm 0.02$; range $0.3-2.24)$ and 1.75 ( \pm 0.036 ; range 0.7-2.79), respectively. The reference values for $\mathrm{Zn}$ $(\mathrm{mg} / \mathrm{l})$ and $\mathrm{Se}(\mu \mathrm{g} / \mathrm{l})$ in these healthy individuals $(\mathrm{n}=379)$ were $1.03( \pm 0.012$; range $0.51-$ 1.9 ) and 88.3 ( \pm 1.02 ; range 51-169.5), respectively.

\section{Discussion}

The role of essential trace elements in health and disease has been largely ignored until recent years. The lack of characteristic signs and symptoms is the main reason for not detecting such deficiencies at an early stage. It was not until 1957 when the importance of major essential trace elements was identified [20]. In 1961, Zn deficiency was first suspected in humans in the Middle East [21] and later was shown to occur in other parts of the world. Zinc is necessary for the growth and multiplication of cells and is responsible for

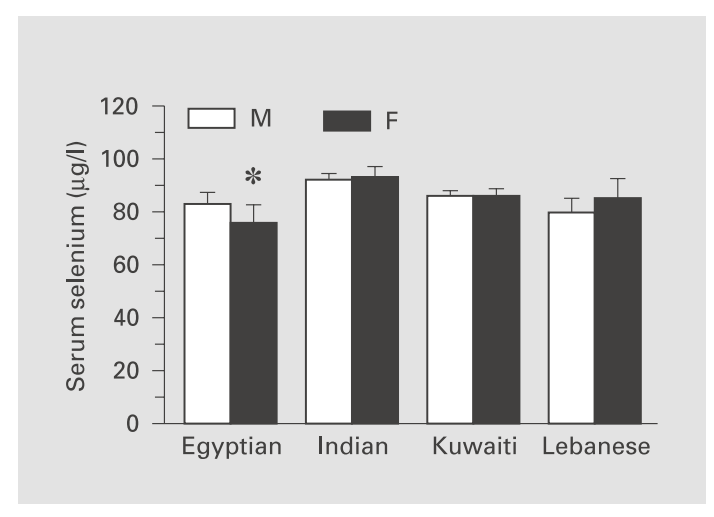

Fig. 5. Serum selenium level in different nationalities in males and females. Mean \pm SEM. F = Female; $M=$ male. ${ }^{*} \mathrm{p}<0.037$ as compared to Indian females.

DNA and RNA synthesis [22]. It is also required for wound healing and skin integrity, as it has a role in the synthesis of proteins such as collagen [5]. This element is also essential for activation of macrophages, polynuclear cells and $\mathrm{T}$ lymphocytes and thus has an important role in anti-inflammatory action in maintaining the integrity of the immune system [23].

Many conditions including cancer and hepatic diseases affect serum $\mathrm{Zn}, \mathrm{Cu}$ and $\mathrm{Se}$ levels [24-29]. Many studies have reported that serum $\mathrm{Zn}$ levels are decreased in some types of malignancies [24]. Elevations in serum $\mathrm{Cu}$ have been reported in some types of neoplasms [30], and hence determination of the serum $\mathrm{Cu} / \mathrm{Zn}$ ratio has been recommended as a prognostic aid [31]. Furthermore, normal physiologic conditions such as pregnancy are also accompanied with changes in the serum level of $\mathrm{Zn}$ and $\mathrm{Cu}$ [32].

Trace elements are important for the protection against free radical-induced tissue damage. Oxygen-derived free radicals have been implicated in the etiology of cardiovascular diseases, inflammatory conditions, autoimmune disorders and cancer [33-37]. 
Like in all the Arabian Gulf States, the population of Kuwait is very heterogenous. Sixty percent are expatriates from different countries with different dietary habits. The reported normal levels from the West may not apply to this area. In this study, we measured the serum levels of the essential trace elements $\mathrm{Zn}, \mathrm{Cu}$ and $\mathrm{Se}$ in a cross section of the adults resident in Kuwait. Normal serum levels of these elements were established. No significant differences were observed in the serum level of $\mathrm{Cu}, \mathrm{Zn}$ and $\mathrm{Se}$ among the four nationalities studied, despite their diverse dietary habits. This conforms with earlier studies performed on different ethnic groups in the US army [38]. This study showed that normally the level of serum $\mathrm{Cu}$ in females was higher than that of males, while there was little gender difference in serum $\mathrm{Zn}$ levels [38]. It has long been recognized that plasma $\mathrm{Cu}$ and ceruloplasmin are higher in women than in men. These differences have been attributed to the effect of female hormones on the metabolism of $\mathrm{Cu}$, due to the fact that indices of $\mathrm{Cu}$ status such as plasma $\mathrm{Cu}$ and ceruloplasmin tend to be elevated with the use of oral contraceptives and in pregnancy [39-41]. In our female healthy volunteers, there was no information regarding the usage of oral contraceptives, which perhaps contributed to the increased level of serum copper. A study from Germany reported mean serum values of $\mathrm{Cu}$ $(\mathrm{mg} / \mathrm{l}), \mathrm{Zn}(\mathrm{mg} / \mathrm{l})$ and $\mathrm{Se}(\mu \mathrm{g} / \mathrm{l})$ in adults to be 1.048, 1.079 and 63.2, respectively [42]. This study, however, did not report gender differences in serum $\mathrm{Cu}$ concentrations. The mean values of serum $\mathrm{Cu}$ and Se were considerably lower in the German study than in ours.

Studies of Se levels in a healthy Spanish population showed a mean value of $80.7 \mu \mathrm{g} / \mathrm{l}$, which is quite close to that of our study [43]. On the other hand, higher mean serum Se values $(122 \mu \mathrm{g} / \mathrm{l})$ were reported in a population from Singapore [44]. The serum $\mathrm{Zn}$ levels in our study were very similar to those reported by Martin-Lagos et al. [45], where the mean concentration of serum $\mathrm{Zn}$ was $0.951 \mathrm{mg} / \mathrm{l}$.

The data in our study show a significantly higher serum $\mathrm{Zn}$ in Lebanese females when compared to that of all other nationalities. The Egyptian females showed a lower Se than Indian females. These observations, however, need to be confirmed in a larger group of Lebanese and Egyptian females, as the present sample size is small.

The data in this study establish the normal values of $\mathrm{Cu}, \mathrm{Zn}$ and $\mathrm{Se}$ in the serum of a cross section of adult residents in Kuwait. The serum levels of these trace elements were not significantly different among the various groups residing in Kuwait. A gender difference was found, showing higher serum $\mathrm{Cu}$ and $\mathrm{Cu} / \mathrm{Zn}$ ratio in females. These results form the basis for larger clinical investigations in the field of trace elements in Kuwait and other countries of the Gulf region.

\section{Acknowledgment}

This study was supported by Kuwait University Grant No. MS-041. 


\section{References}

1 Prasad AS: Clinical, biochemical and nutritional spectrum of zinc deficiency in human subjects: An update. Nutr Rev 1983;41:197-208.

2 Biesel WR: Magnitude of the host nutritional responses to infection. Am J Clin Nutr 1977;30:12361247.

3 Chandra RK: Nutrition, immunity and infection: Present knowledge and future directions. Lancet 1983;i: 688-691.

4 Chandra S, Vyas D, Chandra RK: Trace elements, immunity and susceptibility to infection. Nutr Res 1985;1(suppl 1):693-699.

5 Prasad A: Zinc: An overview. Nutrition 1995;11(suppl):93-99.

6 Akar N, Bahceci M, Ulckan D, Dincer N, Yacuz H, Cavdar AO: Maternal plasma zinc levels after oral zinc tolerance test in pregnancies associated with neural tube defects in Turkey. J Trace Elem Exp Med 1991;4: 225-227.

7 Hsu JM: In Karcioglu ZA, Sarper RM (eds): Zinc and Copper in Medicine. Springfield, Charles C. Thomas, 1980, pp 66-93.

8 Mason KE: A conspectus of research on copper metabolism and requirements of man. Am J Nutr 1979; 109: 1979-2066.

9 Solmons NW: On the assessment of zinc and copper nutrition in man. Am J Nutr 1979; 32:856-871.

10 Bremner I: Absorption, transport and distribution of copper. Ciba Found Symp 1980;79:23-48.

11 Burch RE, Hahn HK, Sullivan JF: Newer aspects of the roles of zinc, manganese and copper in human nutrition. Clin Chem 1975;21:501520.

12 O'Dell BL, Hardwick BC, Reynolds G, Savage JE: Connective tissue defect in the chick resulting from copper deficiency. Proc Soc Exp Bio Med 1961;108:402-406.

13 Shields GS, Coulson WF, Kimbal DA, Carness WH, Cartwright GE, Wintrobe MM: Studies on copper metabolism. XXXII. Cardiovascular lesions in copper deficient swine. Am J Pathol 1962;41:603-617.
14 Bettger WJ, Fish TJ, O'Dell BL: Effect of copper and zinc status of rats on erythrocyte stability and superoxide dismutase activity. Proc Soc Biol Med 1978;158:279.

15 Rotruck JJ, Pope AL, Ganther HE, Swanson AB, Hajeman PG, Hocksta WF: Selenium: Biochemical role as a component of glutathione peroxidase. Science 1973;179:588-590.

16 Awasthi YC, Bentler E, Srivastava SK: Purification and properties of human erythrocyte glutathione peroxidase. J Biol Chem 1975;250: 5144-5149.

17 Schrauzer GN: Selenium in nutritional cancer prophylaxis: An update; in Prasad AS (ed): Vitamins, Nutrition and Cancer. Basel, Karger, 1984, pp 240-250.

18 Hoekstra EG: Biochemical function of selenium and its relation to vitamin E. Fed Proc 1975;34:20832089.

19 McKeehan WL, Hamilton WG, Ham RG: Selenium is an essential trace nutrient for growth of WI-38 diploid human fibroblasts. Proc Natl Acad Sci 1976;73:2023-2027.

20 Johnson HL, Souberlich HE: Trace element analysis in biological samples; in Clinical, Biochemical and Nutritional Aspects of Trace Elements. New York, Liss, 1982, pp 405-426.

21 Prasad AS: Clinical, biochemical and nutritional spectrum of zinc deficiency in human subjects: An update. Nutr Rev 1983;1:197-208.

22 Prasad AS: Clinical, biochemica and pharmacological role of zinc. Annu Rev Pharmacol Toxicol 1979; 20:393-426.

23 Bjogden JD, Oleske JM, Munves EM, Lavenhar MA, Bruening KS Kemp FW, Holding KJ, Denny TN Louria DB: Zinc and immunocompetence in the elderly: Baseline data on zinc nutriture and immunity in unsupplemented subjects. Am J Clin Nutr 1987;46:101-109.

24 Shwartz MK: Role of trace elements in cancer. Cancer Res 1975;35: 3481-3487.
25 Gorodetsky R, Fuks Z, Sulkes A, Ginsburg H, Weshler Z: Correlation of erythrocyte and plasma levels of zinc, copper and iron with evidence of metastatic spread in cancer patients. Cancer 1985;55:779-787.

26 Al-Bader AA, Abul H, Hussain T, Al-Maosawi M, Mathew TC, Dashti $\mathrm{H}$ : Selenium and liver cirrhosis. Mol Cell Biochem 1988;185:1-6.

27 Halstead JA, Smith JC: Plazma zinc in health and disease. Lancet 1970; i:322-324.

28 Al-Bader AA, Mosawi MH, Hussain TA, Dashti HM: Effect of dietary selenium, zinc and allopurinol supplements on plasma and tissue manganese levels in rats with thioacetamide-induced liver cirrhosis. Mol Cell Biochem 1997;173:121-125.

29 Al-Bader AA, Mathew TC, Abul H, Al-Mosawi M, Dashti H, Kumar D, Singal PK: Thioacetamide induced changes in trace elements and kidney damage. J Trace Elem Exp Med 1999;12:1-14.

30 Breiter DN, Diasio RB, Neifeld JP, Roush ML, Rosenberg SA: Serum copper and zinc measurements in patients with osteogenic sarcoma. Cancer 1978;42:598-602.

31 Fisher GL, Byers VS, Shifrine M, Levine AS: Copper and zinc levels in serum from human patients with sarcomas. Cancer 1976;37:356363.

32 Al-Bader A, Hussain T, Al-Mousawi M, Otaibi M, Abul H, Khalifa D, Dashti H: Serum zinc and copper concentrations in pregnant women in Kuwait. J Trace Elem Exp Med 1997;10:209-215.

33 Plaa GL, Witschi H: Chemicals, drugs, and lipid peroxidation. Annu Rev Pharmacol Toxicol 1976;65: 125-141.

34 Proyor WA: Free radical reactions and their importance in biochemical system. Fed Proc 1973;32:18621869 .

35 Haliwell B: Free radical and metal ions in health and disease. Proc Nutr Soc 1987;46:13-26.

36 Bulkley GB: The role of free radicals in human diseases. Surgery 1983;94: 407-411. 
37 Al-Awadi FM, Khan I, Dashti HM, Srikumar T: Colitis-induced changes in the level of trace elements in rat colon and other tissues. Ann Nutr Metab 1997;42:304-310.

38 Johnson HL, Sauberlich HE: Trace element analysis in biological samples; in Prasad AS (ed): Clinical, Biochemical and Nutritional Aspects of Trace Elements. New York, Liss, 1982, pp 405-426.

39 Milne DB, Johnson PE: Assessment of copper status: Effect of age and gender on reference ranges in healthy adults. Clin Chem 1993;39: 883-887.
40 Johnson PE, Milne DB, Lykken GI: Effects of age and sex on copper absorption, biological half-life and status in humans. Am J Clin Nutr 1992;56:917-925.

41 Songchitsomboon S, Komindr S: Serum zinc and copper in healthy adults living in Bangkok and surrounding districts. J Med Assoc Thai 1996;79:550-557.

42 Rukgauer M, Klein J, Kruse-Jarres JD: Reference values for the trace elements copper, manganese, selenium and zinc in the serum/plasma of children, adolescents and adults. J Trace Elem Med Biol 1997;11:9298.
43 Torra M, Rodamilans M, Montero F, Corbella J: Serum selenium concentration of a healthy northwest Spanish population. Biol Trace Elem Res 1997;58:127-133.

44 Hughes K, Chua LH, Ong CN: Serum selenium in a general population of Singapore, 1993 to 1995. Ann Acad Med Singapore 1998;27: 520-523.

45 Martin-Lagos F, Navarro-Alarcon M, Terres-Martos C, Lopez-Garcia de la Serrana H, Lopez-Martinez MC: Serum zinc levels in healthy subjects from southeastern Spain. Biol Trace Elem Res 1998;61:5160. 